\title{
STUDENTS' E-SATISFACTION EXAMINED ONLINE COMMUNITY LEARNING, TECHNOLOGY FIT, AND COMPATIBILITY SEM - MODELLING DURING COVID19 PANDEMIC
}

Manoj Kumar

PhD- Research Scholar, Email: manojk.hnbgu@gmail.com

Postal Address: Department of Business Management, Hemwati Nandan Bahuguna Garhwal Central University, Srinagar,Chauras Campus, Uttarakhand 249161.

Dr. PradeepMamgain(Corresponding Author)

Assistant Professor

Email: pradmamgain@gmail.com

Postal Address: Department of Business Management, P.O. Kilkileswar via Kirtinagar, Tehri Garhwal District, HNBGU Central University, Srinagar, Chauras Campus, Uttarakhand 249161.

\section{Prof. (Dr.) Srinivas Subbarao Pasumarti}

Dean \& Director, Email: ss_pasumarti@yahoo.co.in

Postal Address: School of Management, MIT-World Peace University, Pune, S.No.124, Paud Road, Kothrud, Pune- 411038.

\begin{abstract}
Pandemic outbreaks in student and teaching society have changed seriously. Now, with the influence of COVID19 infection fear, students have dramatically changed their orientational approach. Purposefully, University students aimed at connecting the virtual community for learning, interact, exchange information, and share knowledge. Numerous researched has examined the significant effects of the virtual community, although the present study aims to investigate the collective's e-satisfaction with the student e-learning environment at the university level as regards virtual community interaction, technology fitness, and compatibility. The study attempts to investigate the useful component for strengthening digital learning e-satisfaction by SEM modelling. This study focused on students from universities who take part in $\mathrm{UG}, \mathrm{PG}$ and $\mathrm{PhD}$ programs from various parts of Indian higher education institution or universities. A total 384 number of responses were collected from the above academic intuitions. The study disclosed the importance of virtual community interaction, compatibility, and technology fit to measure e-satisfaction.
\end{abstract}


Keywords: Online Interaction, Virtual Community, Technology Fit, Technological Computability, e-Satisfaction, Digital Education.

\section{Introduction}

Impossibilities always have a variety of future creation opportunities Where there are extreme challenges at the same time with many future possibilities. The duration of COVID19 is a very difficult period for humanity, but it opens up some doors to innovation and adaptation to human survivors. Thus, the COVID19 pandemic is the very first experience for the young generation of University students to face a total lockdown situation in the country. Likewise, students' slow processes have also suffered from the massive spreading of COVID19 infections, while families have been both concerned about their children's virus infection and academic future. Initially, the World Health Organisation, the WHO, considered that the incursion of the Virus into the world was a rare pneopulmonary activity. However, in March 2020, the Virus Pandemic was stated(Buranyi, 2020; Li et al., 2020), which resulted in the majority of nations attempting to control the virus's dispersal(Sharun et al., 2020).

Furthermore,(Morens et al., 2009) was described as "the pandemic" as one line cannot be defined. A virus has greater or globally affected geographical expansion; dispersal of the disease from one place to another may be traced; it takes very few times to achieve multiple cases at the explosive rate of transmission, resulting the human body is not immune-producing; and the newness of the new variant of the disease once existed. Deceptively, many countries have a dispute over the declaration of COVID19 as a pandemic with the World Health Organization (WHO) (Buranyi, 2020). WHO was indeed criticized negatively by the deferent nation and the political argument that transparent information was not communicated to the public by the organization?

Traditionally, the teaching and learning processes are somehow dependent on direct teaching pedagogy(Hayter \& Parker, 2019; Murillo-Zamorano et al., 2019); after COVID19 the teaching and learning scenarios are entirely changing the Universities facing challenges to continue impactful teaching and learning process. In the context of modern teaching, methodologies are significantly changing the pattern and attitude of young generation students. Despite the technical skills of the teachers and the teaching practices are significantly controlled by Information and Communication Technology (ICT), internet 
network becomes the capability hindrance of technical skills of educator and students(Jung \& Lee, 2018). Nowadays teaching practices in higher education institutions and student learning processes based on web technologies, because of this pandemic education system has unique opportunities to build a technology-based learning environment. Moreover, the successive use of Web 4.0 enabled technologies transforming the higher education system, universities and colleges are rapidly adopting these changes(Schwarzenberg et al., 2018). Sequentially, web-based learning interest of university students are rapidly changing around the world(Kurucay \& Inan, 2017), young generation university students are showing more interest in online learning system because of generation characteristics.

\subsection{Significance of the study}

Details of the study on the collaborative collective impact of a virtual community, compatibility, technology fitness and assistance for university-level students on eclassroom satisfaction. The previous study constructs the community motivation in an online learning satisfaction(Bhattacherjee, 2001; Liu \& Beldona, 2021; Vijay et al., 2019; Wang et al., 2019), students compatibility features of e- classroom learning(Ifinedo, 2012; Zhang et al., 2014),

Technological collaborative virtual learning

system increasingly being updated in technology fit adopted from(Lu \& Yang, 2014; McGill \& Klobas, 2009). Therefore, the proposed study attempts to perform the statistical validation of constructs and the respective scale in the Indian context. This study has been structured in the following direction. A preliminary review of the literature and associated constructs been explained in the respective section. Related constructed hypotheses, sample and measurement are explained in the next section. Lastly, the result of the study is explained hereafter discussion and future potential of the research presented.

The purpose of this research was to find out the collective relationships of the virtual community, compatibility, technology fit and determine how these collaborative factors are influences students e-satisfaction. Following research questions guided the research study-

1. Find out the linkages between a virtual community, system compatibility, technology fit and online learning environment.

2. How these factors (Virtual community, compatibility, and Technology fit) structurally justifying the students e-class satisfaction. SSN (Print): 2204-0595 ISSN (Online): 2203-1731 
education day by day. During literature view the selective keywords interchangeably use like online learning, virtual learning, distance education etc. the virtual earning never held without IT gadgets such as laptop, computer, tablets, smartphones, webcam, and efficient internet connectivity(Mayer, 2019). Formerly, we noted that the government education policy endorses virtual leaning interaction and encourage students to incorporate the technologies in education, and successive development of student learning. The main advantages of virtual learning forums build knowledge in wide view(Tenório et al., 2020), virtual learning facilitates a convenient and flexible learning system. Moreover, virtual leaning forums provides flexibility schedule and accessibility for the students it is all time available whenever they want to access it(Aldholay et al., 2019). Worldwide governments are announcing and instructed their educational institutions for creating as well as adopting internet-based learning system because successive developments of the notions significantly depend on young generation education, skill, reskill and upskilling(Tavassoli \& Karlsson, 2016).Therefore, internet embedded electronic devices are computer, laptop, smartphone, tablet, and other portable devices are loaded with online learning software which is assists the students in the online learning process.

\section{Review of literature and hypotheses development}

This section provides insight into appropriate literature review for the various research constructs being used in the research study. Designing relevant hypotheses exploring the possible association with the dependent variable.

2.1. Virtual Interaction: The theory of Virtuality explained the communication performed face to face interaction from two deferent end and it's controlled or moderated by internet network and computer devices(Mesmer-Magnus et al., 2011). In the context of the COVId19 pandemic, the education communities are significantly facing a challenge to control the virus infection rate and create a safe environment. Online learningbenefits for students extensively considered, some important reimbursements profiles are explained;

- e-Class leaning system gives flexibility to the position;

- Saves time and costs;

o opportunities to create a collaborative learning environment that is not necessary for the presence of individuals;

○ Unlimited learning option and study material available; 
- Agreement for the acquisition and preservation of updated knowledge.

E-learning could be elucidated as the computer network technology-enabled system mainly connected by the internet, individual interaction and knowledge delivered via proper channel. During the COVID19 situation, University and colleges radically adopted electronic learning environment the term e-learning classified likewise computer-enabled learning, online learning, web-based learning, virtual learning such terms are attracting researcher to the research(Al-Fraihat et al., 2020; Hrastinski, 2008; Venkatesh \& Bala, 2008). Additionally, after 2010 Indian universities or higher education institutions radically adopted computer-based learning, the massive user of the internet continuously increasing. In fact, educational institution willingly interacts with students, virtual interaction defined potential collaborative opportunities to the learner as well as organization. Hence, internet technologies gradually distributed to small institutes and schools(Jacovkis, n.d.)even though the economic family are also prerequisite technological equipment and internet connection(Cabero-Almenara et al., 2019). The advancement of Internet technology pushed to upgrade or innovate computercommunity very much depend on some geographical local and common interest of human relations. Now modern, communication not limited to geographical location because of the internet and web communication revolution, although the modern community thinking beyond the geographical soundings and interest(Cheng, 2016; Kim et al., 2020). Increasingly, virtual community becomes more specific, exciting, and providing space to interact with virtual strangers(Chou, 2020). As the objective of virtual learning online communities provided opportunities to share your information among the group member and a high chance to find the possible or most appropriate solution for your problems(Jang et al., 2008; Wang et al., 2019). Eventually, the common activity interest in the virtual platform the individual feels more attached just like a traditional geographic influenced community. In the virtual community, the sense of communication and common interest is the basic component for the 
accomplishment of the virtual community(Cheng, 2011; Kim et al., 2009; Liu \& Beldona, 2021). Moreover, the perceptual comparison of the community members and the intention to corporate with other members is the feeling of belongingness, member feels secure during community activities(Rosenbaum et al., 2005). On the other hand, individual feel free ethically supported and emotionally safe under community edge(Rosenbaum et al., 2005), the community also encourage vulnerability within the belongingness even member may not be faced ever in real life(Colombo et al., 2001).

The community member may influence the behaviour of another member into the belonging group, somehow the community member feels it's an authority to influence(McMillan \& Chavis, 1986). Broadly, virtual community members are available virtually every time according to the convenience of the member could share information or query the other member will respond without any time limitation(Kim et al., 2020; Rosenbaum et al., 2005). Therefore, individuals are joining the community as per their preference, need, willingness, priority, and goal of learning; the desired aim increase satisfaction(Mesmer-Magnus et al., 2011).
H1: Virtual Community has a direct and positive effect on Students e-Class Satisfaction.

\subsection{Compatibility Trials}

System compatibility is the fundamental issues with generation $-Z$ users' adoption of innovative technology or application(Cheng, 2015). Nevertheless, the intensity of the user compatibility predicted the innovation and previewed determent of information system (IS) to align by the influence of user requirement, experience, present values, and knowledge basis(Bilgihan et al., 2016; Rogers, 1995). Therefore, the findings of the study pointing out the compatibility of the technologies and information system significantly changed the learning process mode, resulting from its successive adaptational intent of learner could influence the satisfaction as well. Same as, Premkumar, (2003) noted that the users are attracted to new or innovative technology which can solve current leaning needs. Fundamentally, the compatibility of information system drawing significate attention to virtual education pattern(Kim et al., 2005; Xie et al., 2020). Sequentially, for information system technology adaptation compatibility always leads; some research highlighted that the compatibility has a considerable impact on the user's satisfaction(Isaac et al., 2019; Ozturk et al., 
2016). Present research study intuition described the virtual learning technologies fit for university students' lifestyle. According to the findings of (Islam \& Azad, 2015), technological compatibility has a significant impact on user e-satisfaction and one more author (Cheng, 2016) confirmed a meaningful relation between user's compatibility and satisfaction. This study tries to investigate the information system compatibility impact on user's satisfaction.

H2: Compatibility has a direct and positive effect on Students e-Class Satisfaction

\subsection{Technology Fit}

In virtual or online learning, technology plays an essential role Technology fit is described as the best possible concentration of the system technology that works adequately and satisfies customer needs(Isaac et al., 2019; Lin \& Wang, 2012). Extensively, technologies increase individual efficiency, efficiency and performance throughout online learning or work(Lu \& Yang, 2014; Negahban \& Chung, 2014). Similarly, technology characteristics properly take into consideration asper's task need to choose the most appropriate or fit once because the technology assists continuously during work assignment. Hence, adequate technology knowledge remains the top priority for the individual to choose the appropriate technology that must be compatible with the task concerned(Goodhue \& Thompson, 1995; Lin \& Lu, 2011). Numerous, Studies investigated the positive link between fit and performance of the technology. The present study tries to investigate the use of technology fit on user satisfaction for the validation and direction of the hypothesis proposed

H3: Technology Fit has a direct and positive effect on Students e-Class Satisfaction.

Table 1: Formulated Hypotheses

\begin{tabular}{|c|c|c|c|}
\hline $\begin{array}{l}\text { Independe } \\
\text { nt } \\
\text { Variable }\end{array}$ & $\begin{array}{l}\text { Depende } \\
\text { nt } \\
\text { Variable }\end{array}$ & $\begin{array}{l}\text { Hypothes } \\
\text { es }\end{array}$ & Outcomes \\
\hline $\begin{array}{l}\text { Virtual } \\
\text { Community }\end{array}$ & $\begin{array}{l}\text { e- Class } \\
\text { Satisfacti } \\
\text { on }\end{array}$ & H1 & $\begin{array}{l}\text { Virtual } \\
\text { Community } \\
\text { has a direct } \\
\text { and } \\
\text { positive } \\
\text { effect on e- } \\
\text { Class } \\
\text { Satisfaction }\end{array}$ \\
\hline $\begin{array}{l}\text { Technology } \\
\text { Fit }\end{array}$ & $\begin{array}{l}\text { e- Class } \\
\text { Satisfacti } \\
\text { on }\end{array}$ & H2 & $\begin{array}{l}\text { Technology } \\
\text { Fit has a } \\
\text { direct and } \\
\text { positive } \\
\text { effect on e- } \\
\text { Class } \\
\text { Satisfaction }\end{array}$ \\
\hline $\begin{array}{l}\text { Compatibili } \\
\text { ty }\end{array}$ & $\begin{array}{l}\text { e- Class } \\
\text { Satisfacti } \\
\text { on }\end{array}$ & H3 & $\begin{array}{l}\text { Compatibili } \\
\text { ty has a } \\
\text { direct and } \\
\text { positive } \\
\text { effect on e- } \\
\text { Class } \\
\text { Satisfaction }\end{array}$ \\
\hline
\end{tabular}

\subsection{Satisfaction Apprehensions}

Satisfaction is the user's psychological state that would be the consequence of constructive experience. Sequentially, the 
users' most essential advanced technologies or system satisfaction indicators in order to satisfy the users and the organization's priorities and needs(DeLone \& McLean, 2016). The positive association of the Internet portal infrastructure, responsiveness, adaptability and the individual's user-friendly platform create a positive impact on satisfaction(Lee \& Lehto, 2013). Therefore, user satisfaction could indicate how e-portal responses are always enhanced all through working progress, likely to result in the expected responses are always increasing satisfaction(Isaac et al., 2019; Xinli, 2015). The basic user satisfaction antecedents indicate new system adaptation somehow influenced by system technologies compatibility, the university students leaning is collectively depended on technological availability and have very limited time to compatible with online learning portal as well as virtual communities. Additionally, user satisfaction dependent on various antecedents likewise functions, quick response, and userfriendliness(Alalwan, 2020; Xinli, 2015), online learning students identify satisfaction on their interest and collective intuition of learning. Numerous previous studies findings have confirmed that user esatisfaction in information system practices played a crucial role in the context of technological application. The construct and item of e-satisfaction was study adopted from various appropriate available studies(Bhattacherjee, 2001; Huang, 2008; Sun et al., 2008; Vijay et al., 2019; Wang et al., 2019).

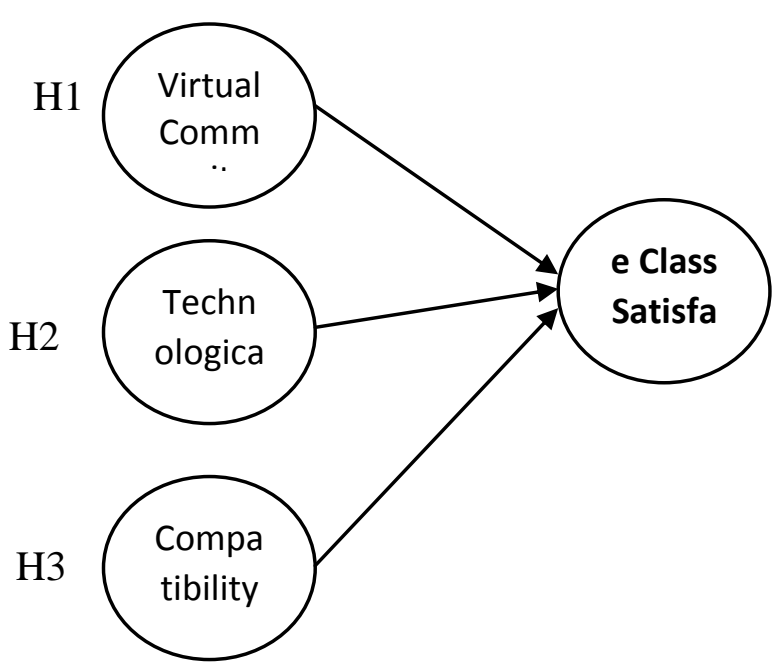

Figure 1: Conceptual Framework and Hypotheses.

\section{Methodology}

\section{Instrument Selection}

Purposefully, the authors utilized appropriate literature review for the research construct related to virtual learning, virtual community, online learning, technology fit, system compatibility and e-satisfaction. Virtual learning and community based online learning system having sixteen items which are internally categorized into fourpart first four items belongs to the membership, second part five to nine items represent influence and relatedness, the third part has four items from ten to thirteen 
belongs to integration and fulfilment of a need, and last part of the section represents emotional connection having last three items form fourteen to sixteen all items adopted form several sources(Bressler \& Grantham, 2000; Davidson \& Cotter, 1986; Kim \& Kim, 2004; McMillan, 1996). Similarly, other three constructs and respective items were adopted from existing studies; compatibility construct related items adopted from(P. Ifinedo, 2012; RuizEquihua et al., 2019); Technology fit construct belonging one item was selfdeveloped and rest were adopted from( $\mathrm{Lu} \&$ Yang, 2014; McGill \& Klobas, 2009; Negahban \&Chung, 2014); lastly, the construct e-satisfaction identification adopted form(Bhattacherjee, 2001; Huang, 2008; Sun et al., 2008; Vijay et al., 2019) and few were self-developed.

\section{Phase I - Developing the Scale for e-Class}

\section{Learning Satisfaction in the Indian context}

The study was carried out with an adaptive scale questionnaire the items were select for virtual community learning from(Bressler \& Grantham, 2000; Davidson \& Cotter, 1986; Kim \& Kim, 2004; McMillan, 1996; McMillan \& Chavis, 1986) studies were authenticated and validated in deferent countries context. Followed by selected items for compatibility(Ifinedo, 2012; Wang et al., 2017), technology fit(Lu \& Yang,
2014; McGill \& Klobas, 2009; Negahban \& Chung, 2014)and e-satisfaction form (Bhattacherjee, 2001; Huang, 2008; Sun et al., 2008; Vijay et al., 2019; Wang et al., 2019).

The all-selected items were measured on seven-points of Likert scale classify " $1=$ strongly disagree" to " $7=$ Strongly agree". All items like declarative statements customer free show their agreement on provided scale measurement, except the demographic description all main construct question in the form of close-ended. In the study statistical calculation and analysis performed on IBM SPSS 26 tool pack and AMOS 26 used for SEM.

\section{Phase II - Scale Reliability Retest (Mini Pilot Survey)}

A mini-pilot study was conducted formerly main study response administration at the stage of pilot study items contents modified on the ground of expert's suggestions of the respective area and selected populations respondents. The modification included grammatical correction, replacing item name, and additional appropriate item added after expert suggestion and respondent observation. Complete questionnaire test and validated prior main study data collection. Additionally, during the pilot study Cronbach's reliability coefficient and factors calculated, the reliability test was 
calculated on 30 items divided into four segments three independent variables namely virtual community (16 items), compatibility (3 items), technology fit (4 items), and outcome variable e-satisfaction (7 items). In the pilot survey, 80 respondents contacted but only 48 were returned feedback after that only 45 were found suitable for examination.

\section{Phase III - Scale Validation}

Finally, the study was conducted, examine, and validate the scale. The stratified convenient sampling design was adopted for sample belong to $\mathrm{UG}, \mathrm{PG}$ and $\mathrm{PhD}$ programme University students who are engaged or adopted virtual community learning system. More than 800 hundred questionnaires were communicated to the respondents from various Indian locations like Srinagar, Roorkee, Dehradun, Cuttack, Bhubaneswar, Raurkela, Silchar and Bilaspur.

\section{Study context}

The first-hand data was collected by direct mail of self-administrated and adoptive scaled questionnaire during lockdown phase from various public and private sector Universities \& others academic institutions, belongs to Uttarakhand, Odisha, Chhattisgarh, and Assam students. However, from the above academic institutions, 
of incomplete, unsatisfactory, and duplicate or doubtful responses.

\section{Empirical analysis:}

The section provides a brief picture of the sample, interpretation of the data, executed test and the result as well. An empirical analysis carried out by the direction of(Hair et al., 2010). The model assessment was done through confirmatory factor analysis (CFA) and structural equation modelling (SEM) executed for model fitness.

\section{Demographic description}

Sample demographic profile explained in table 1 , the total number of respondents is 392 in which 230 females (58.8\%), 154 males (39.3\%) and 8 respondents did not prefer to disclose their gender that is $2 \%$ only. The age classification of respondents was under 20 about $39.3 \%$, between 21 to 24 about $50.5 \%, 25$ to 24 about $7.1 \%$, and above 31 only 2.6\%. Majority of respondents studying into $\mathrm{UG}$ and $\mathrm{PG}$ jointly $84 \%$ of the total respondent's percentage.

\begin{tabular}{|l|l|l|l|}
\hline $\begin{array}{l}\text { Demographic } \\
\text { Items }\end{array}$ & Categories & $\mathbf{N}$ & $\begin{array}{l}\text { Percentage } \\
(\%)\end{array}$ \\
\hline Gender & Female & 230 & 58.7 \\
\cline { 2 - 4 } & Male & 154 & 39.3 \\
\cline { 2 - 4 } & $\begin{array}{l}\text { Prefer not } \\
\text { to say }\end{array}$ & 8 & 2 \\
\hline \multirow{2}{*}{ Age } & Under- 20 & 156 & 39.8 \\
\cline { 2 - 4 } & $21-24$ & 198 & 50.5 \\
\cline { 2 - 4 } & $25-30$ & 28 & 7.1 \\
\hline
\end{tabular}

Copyright $\odot$ Author

\begin{tabular}{|l|l|l|l|} 
& $31-$ above & 10 & 2.6 \\
\hline Education & PhD & 20 & 5.1 \\
\cline { 2 - 4 } & PG & 94 & 24 \\
\cline { 2 - 4 } & UG & 247 & 63 \\
\cline { 2 - 4 } & Other & 31 & 7.9 \\
\hline
\end{tabular}

Table 2: Sample Demographics Characteristics.

Source: Primary data.

\section{Data interpretation}

Collated data were processed in SPSS 26.0 research analysis software, followed by analyzed structural equation modelling (SEM) the steps to data analysis suggested byHair et al., (2006) Hair et al., (2006). Confirmatory factor analysis (CFA) conducted for the estimation measurement model and testing the model fit as well as hypotheses testing.

\section{Model Measurement}

Model psychometric features are investigated via ground of the following points: internal consistency of constructs and items, followed by convergent and discriminant validities. Item's loadings more than 0.5 are satisfactory and values less than were deleted or fixed form the scale also(Hair et al., 2010). The research model consists of three independent variables (virtual community interaction, Compatibility, and technology fit) and one dependent variable (e-Satisfaction). Sequentially, three hypotheses were tested in 
this model followed by factors validated and four research constructs comprised for CFA.

The result calculated and displayed in table 3 which included four constructs, thirty items, factors loadings, average variance extracted (AVE) of the construct recommended 0.50 preferably adequate, Cronbach's alpha $(\alpha)$, and composite reliability (CR) of the study were above 0.7 suggested(Fornell \& Larcker, 1981; Joe F Hair et al., 2012).

Table 3: Construct and scaled items.

\begin{tabular}{|c|c|c|c|c|c|c|}
\hline onstructs & Items (Indicators) & $\begin{array}{l}\text { Adopted from } \\
\text { (Reference) }\end{array}$ & $\begin{array}{l}\text { Factor } \\
\text { Loading } \\
\text { Reliability }\end{array}$ & AVE & Cronbach's & $\begin{array}{l}\text { Composite } \\
\text { Reliability }\end{array}$ \\
\hline & & & & & $(\alpha)$ & (CR) \\
\hline \multirow{16}{*}{$\begin{array}{l}\text { Online } \\
\text { Community } \\
\text { Learning }\end{array}$} & Information Exchange & \multirow{16}{*}{$\begin{array}{l}\text { Davidson \& } \\
\text { Cotter, (1986); } \\
\text { Isaac et al., } \\
\text { (2019); Kim \& } \\
\text { Kim, (2004); } \\
\text { McMillan, } \\
(1996)\end{array}$} & 0.772 & \multirow[t]{16}{*}{611} & \multirow[t]{16}{*}{0.87} & \multirow[t]{16}{*}{0.81} \\
\hline & Suggestions & & 0.812 & & & \\
\hline & Participation & & 0.791 & & & \\
\hline & Belongings & & 0.897 & & & \\
\hline & Idea generation & & 0.893 & & & \\
\hline & Quality participation & & 0.75 & & & \\
\hline & Reflection of opinion & & 0.764 & & & \\
\hline & Responsibility & & 0.794 & & & \\
\hline & Common Interest & & 0.815 & & & \\
\hline & Information usefulness & & 0.804 & & & \\
\hline & $\begin{array}{l}\text { Requirements of virtual } \\
\text { community }\end{array}$ & & Deleted & & & \\
\hline & $\begin{array}{l}\text { Ability and exchange of } \\
\text { information }\end{array}$ & & 0.887 & & & \\
\hline & $\begin{array}{l}\text { Members of information } \\
\text { satisfaction }\end{array}$ & & Deleted & & & \\
\hline & $\begin{array}{l}\text { Importance of new } \\
\text { members }\end{array}$ & & 0.892 & & & \\
\hline & Membership duration & & 0.912 & & & \\
\hline & $\begin{array}{l}\text { Forthcoming } \\
\text { involvement }\end{array}$ & & 0.893 & & & \\
\hline \multirow[t]{3}{*}{ Compatibility } & $\begin{array}{l}\text { Compatible with } \\
\text { standards }\end{array}$ & \multirow{3}{*}{$\begin{array}{l}\text { Ifinedo et al., } \\
\text { (2019);Ifinedo, } \\
\text { (2012); } \\
\text { Kolodinsky et } \\
\text { al., (2004); } \\
\text { Wang et al., } \\
\text { (2017) }\end{array}$} & 0.988 & \multirow[t]{3}{*}{0.885} & \multirow[t]{3}{*}{0.892} & \multirow[t]{3}{*}{0.922} \\
\hline & $\begin{array}{l}\begin{array}{l}\text { Compatible with the } \\
\text { existence }\end{array} \\
\end{array}$ & & 0.89 & & & \\
\hline & $\begin{array}{l}\text { Compatible with } \\
\text { requirements }\end{array}$ & & 0.96 & & & \\
\hline \multirow[t]{4}{*}{$\begin{array}{l}\text { Technology } \\
\text { fit }\end{array}$} & $\begin{array}{l}\text { Fits with the current } \\
\text { learning style }\end{array}$ & \multirow{4}{*}{$\begin{array}{l}\text { Isaac et al., } \\
\text { (2019); Lu \& } \\
\text { Yang, (2014); } \\
\text { McGill \& } \\
\text { Klobas, } \\
\text { (2009); } \\
\text { Negahban \& } \\
\text { Chung, (2014) }\end{array}$} & 0.857 & \multirow{4}{*}{0.689} & \multirow{4}{*}{0.897} & \multirow{4}{*}{0.972} \\
\hline & $\begin{array}{ll}\begin{array}{l}\text { Suitability } \\
\text { coursework }\end{array} & \text { for } \\
\end{array}$ & & 0.867 & & & \\
\hline & $\begin{array}{l}\text { Essential for work } \\
\text { responsibilities }\end{array}$ & & 0.801 & & & \\
\hline & $\begin{array}{l}\text { Computer and Internet } \\
\text { Fits (Self-develop) }\end{array}$ & & 0.793 & & & \\
\hline \multirow[t]{2}{*}{$\begin{array}{l}\text { e-Satisfaction } \\
\text { Identification }\end{array}$} & $\begin{array}{l}\text { Satisfied - performance } \\
\text { of network and } \\
\text { educators }\end{array}$ & \multirow{2}{*}{$\begin{array}{l}\text { Bhattacherjee, } \\
(2001) ; \\
\text { Huang, } \\
(2008) ; \quad \text { Isaac }\end{array}$} & 0.867 & \multirow[t]{2}{*}{0.751} & \multirow[t]{2}{*}{0.874} & \multirow[t]{2}{*}{0.799} \\
\hline & Satisfied - an experience & & 0.844 & & & \\
\hline
\end{tabular}




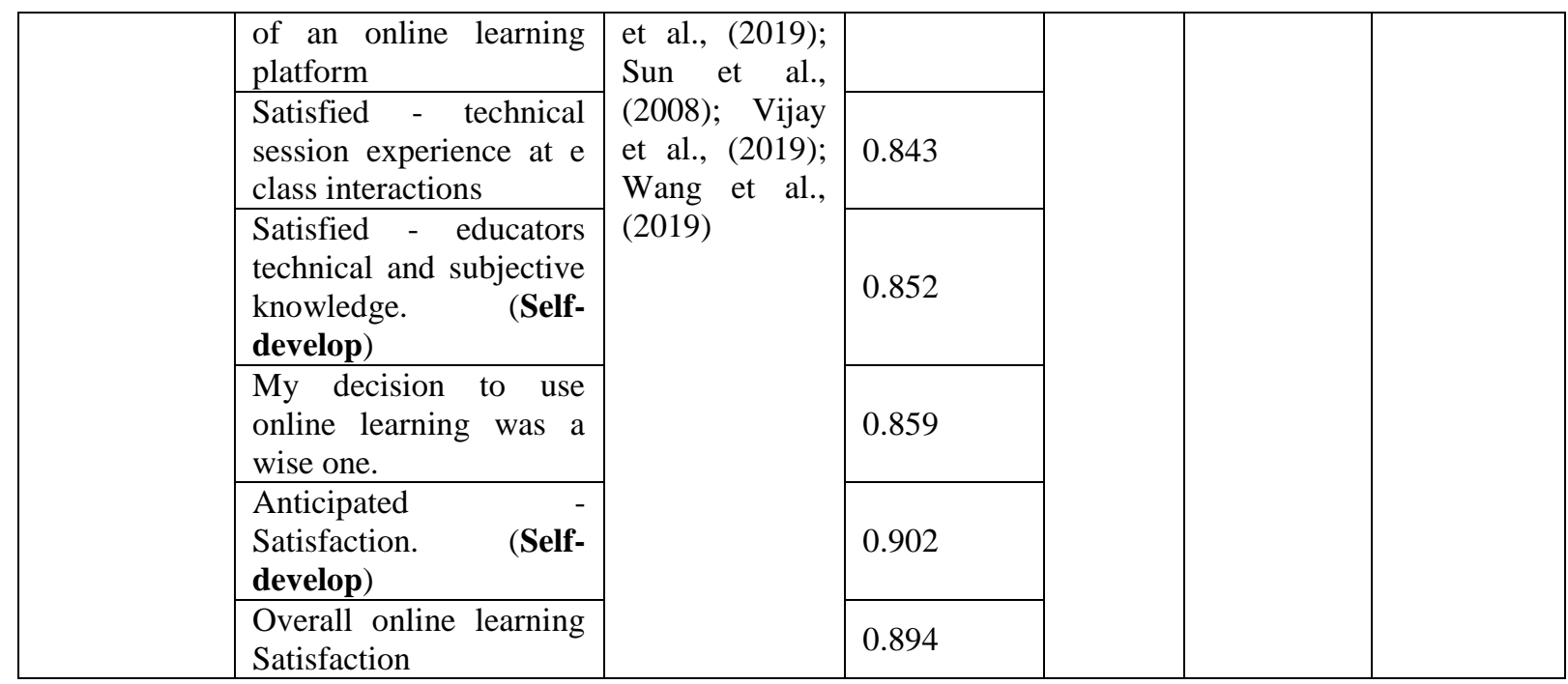

Note: VCI: Virtual Community Interaction, CPT:

Compatibility, TechF: Technology fit, SatId:

Satisfaction Identification.

\begin{tabular}{|c|c|c|c|c|}
\hline & VCI & CPT & TechF & SatID \\
\hline VCI1 & 0.772 & 0.657 & 0.508 & 0.420 \\
\hline VCI2 & 0.812 & 0.580 & 0.498 & 0.424 \\
\hline VCI3 & 0.791 & 0.650 & 0.500 & 0.512 \\
\hline VCI4 & 0.897 & 0.656 & 0.603 & 0.475 \\
\hline VCI5 & 0.893 & 0.576 & 0.446 & 0.440 \\
\hline VCI6 & 0.750 & 0.581 & 0.582 & 0.523 \\
\hline VCI7 & 0.764 & 0.622 & 0.552 & 0.462 \\
\hline VCI8 & 0.794 & 0.564 & 0.512 & 0.465 \\
\hline VCI9 & 0.815 & 0.588 & 0.522 & 0.464 \\
\hline VCI10 & 0.804 & 0.571 & 0.504 & 0.443 \\
\hline VCI12 & 0.887 & 0.448 & 0.427 & 0.425 \\
\hline VCI14 & 0.892 & 0.499 & 0.448 & 0.476 \\
\hline VCI15 & 0.912 & 0.506 & 0.449 & 0.490 \\
\hline VCI16 & 0.893 & 0.559 & 0.539 & 0.555 \\
\hline CPT1 & 0.574 & 0.988 & 0.544 & 0.601 \\
\hline CPT2 & 0.508 & 0.890 & 0.463 & 0.547 \\
\hline CPT3 & 0.391 & 0.960 & 0.367 & 0.532 \\
\hline TechF1 & 0.326 & 0.372 & 0.857 & 0.446 \\
\hline TechF2 & 0.263 & 0.341 & 0.867 & 0.398 \\
\hline TechF3 & 0.452 & 0.542 & 0.801 & 0.527 \\
\hline TechF4 & 0.469 & 0.556 & 0.793 & 0.552 \\
\hline SatId1 & 0.450 & 0.513 & 0.508 & 0.867 \\
\hline SatId2 & 0.476 & 0.556 & 0.537 & 0.844 \\
\hline SatId3 & 0.456 & 0.517 & 0.499 & 0.843 \\
\hline SatId4 & 0.481 & 0.547 & 0.502 & 0.852 \\
\hline SatId5 & 0.436 & 0.525 & 0.503 & 0.859 \\
\hline SatId6 & 0.417 & 0.516 & 0.512 & 0.902 \\
\hline SatId7 & 0.404 & 0.508 & 0.493 & 0.894 \\
\hline
\end{tabular}

\begin{tabular}{|l|l|l|l|l|l|l|}
\hline Construct & VCI & CPT & TechF & SatID & Mean & SD \\
\hline VCI & $\mathbf{0 . 7 9}$ & & & & 5.01 & 1.01 \\
\hline CPT & 0.587 & $\mathbf{0 . 8 0 1}$ & & & 4.99 & 1.87 \\
\hline TechF & 0.576 & 0.532 & $\mathbf{0 . 7 9 9}$ & & 6.1 & 0.87 \\
\hline SatID & 0.612 & 0.601 & 0.597 & $\mathbf{0 . 8 6 3}$ & 5.18 & 1.23 \\
\hline
\end{tabular}

Table 5: Discriminant Validity of Latent

Constructs Dimensions

Note :

a) Virtual Community Interaction (VCI), Compatibility (CPT), Technology fit (TechF) and Satisfaction Identification (SatID).

b) Diagonal values represent the square root of AVE, all the other values denote the correlation coefficients.

Structural model assessment and hypotheses testing

Figure 2 and Table 6 explained the SEM assessments that elucidate the various hypotheses findings tests. Here, overall quality of model predict virtual community impact on e-class satisfaction $\mathrm{H} 1$ is acceptable $(\beta=0.296, \mathrm{t}=2.751, \mathrm{p} \leq 0.001)$. Similarly, technology fit predicts e-class satisfaction $\mathrm{H} 2$ is acceptable with $(\beta=$ $0.317, \mathrm{t}=3.984, \mathrm{p} \leq 0.001)$ and 
Compatibility of e-class satisfaction is also acceptable with $(\beta=0.423, \mathrm{t}=4.135, \mathrm{p} \leq$ 0.001). The SEM models explain significate information about research data and direction of hypothesized path relationship by using coefficient $(\beta)$ and square $R\left(R^{2}\right)$. According to Chin (1998), the relationship strength indicated by the $\mathrm{R}^{2}$ value and its shows the percentage of model variance indicates the analytical power. The SEM obtained results of the study indicates that the model structurally fit and it holds satisfactory analytical performance.

Table 6: SEM model result

\begin{tabular}{|c|c|c|c|c|c|}
\hline $\begin{array}{l}\text { Num } \\
\text { ber }\end{array}$ & $\begin{array}{l}\text { Hypothe } \\
\text { sized } \\
\text { path }\end{array}$ & $\begin{array}{l}\text { Estim } \\
\text { ate } \beta\end{array}$ & $\begin{array}{l}\text { t- } \\
\text { val } \\
\text { ue }\end{array}$ & $\mathbf{p} \leq$ & $\begin{array}{l}\text { Resul } \\
\mathbf{t}\end{array}$ \\
\hline $\mathrm{H} 1$ & $\begin{array}{l}\text { Virtual } \\
\text { Commun } \\
\text { ity } \rightarrow \text { e- } \\
\text { Class } \\
\text { Satisfacti } \\
\text { on }\end{array}$ & 0.295 & $\begin{array}{l}2.7 \\
51\end{array}$ & $\begin{array}{l}0.0 \\
01\end{array}$ & $\begin{array}{l}\text { Accep } \\
\text { ted }\end{array}$ \\
\hline $\mathrm{H} 2$ & $\begin{array}{l}\text { Technolo } \\
\text { gy Fit } \\
\rightarrow \quad \text { e- } \\
\text { Class } \\
\text { Satisfacti } \\
\text { on }\end{array}$ & 0.317 & $\begin{array}{l}3.9 \\
84\end{array}$ & $\begin{array}{l}0.0 \\
01\end{array}$ & $\begin{array}{l}\text { Accep } \\
\text { ted }\end{array}$ \\
\hline $\mathrm{H} 3$ & $\begin{array}{l}\text { Compatib } \\
\text { ility } \\
\rightarrow \quad \text { e- } \\
\text { Class }\end{array}$ & 0.423 & $\begin{array}{l}4.1 \\
35\end{array}$ & $\begin{array}{l}0.0 \\
01\end{array}$ & $\begin{array}{l}\text { Accep } \\
\text { ted }\end{array}$ \\
\hline
\end{tabular}

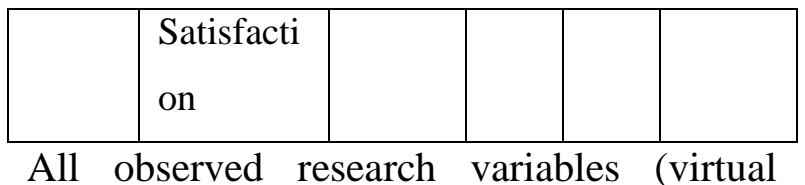

community interaction, Technology fit, compatibility), were found positive and significant influence on e-class satisfaction. Therefore, on the ground of hypothesized path analysis, all three hypotheses accepted and the model also was able to found significant $R^{2}=67$ percentage of variance eclass satisfaction.

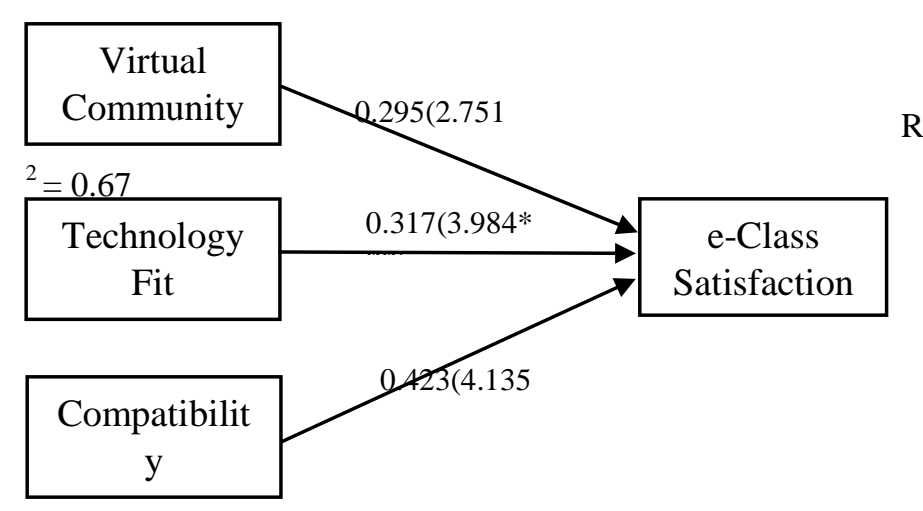

Figure 2: Structural model

\section{Discussion}

This study, exploring the possible linkages among virtual community interaction (VCI), Technology Fit (TF), compatibility and eclass satisfaction of the university students who were engaged in $\mathrm{UG}, \mathrm{PG}, \mathrm{PhD}$, and other courses. The authors tried to address the previous research gap by collecting data from the sample in the Indian higher education context and future research directions are also provided. Similarly, this study highlighted the importance of VCI, TF and compatibility to enhanced the students 
e-class satisfaction during their higher education degree completion. The structural equation modelling (SEM) results provided the suitability of model fit for the proposed conceptual research framework.

\section{Research Implication:}

This research study is also having some managerial or practical application for University students and others, the interest of virtual community use for learning. Therefore, technological fitness and technological compatibility become a necessity to adopt information technology or online leaning solutions. So that, this study provides some impactful evidence for online leaning suitability and e-class satisfaction. To the end of this research authors findings indicated that the fusion of both theoretical and empirical linkages developed a better understanding. Nowadays, online learning becomes a passionate identity among the new generation of students.

\section{Limitation and future research direction:}

In this research, the study authors used selfreported adoptive scaled instruments for data collection. Mostly, the results of the interpretation are depending on the construct and the instrument was used. Methods EFA and CFA was employing initial for items qualifications are construct justification. The sample size of the study is small and adequate for SEM, the study adopted a convenient sampling technique for data collection. Furthermore, the authors suggested that for further investigation with additional suitable constructs and item that are significantly influenced the e-class learning satisfaction or try to investigate how satisfaction develop the sustainable performance of the students. This study only considers University students, another level of students of individuation might change the results and explore the other level of research dimensions.

\section{References}

[1]. Alalwan, A. A. (2020). Mobile food ordering apps: An empirical study of the factors affecting customer e-satisfaction and continued intention to reuse. International Journal of Information Management, 50, $28-44$.

https://doi.org/10.1016/j.ijinfomgt.2019.04.0 08

[2].Aldholay, A., Abdullah, Z., Isaac, O., \& Mutahar, A. M. (2019). Perspective of Yemeni students on use of online learning. Information Technology \& People. https://doi.org/10.1108/ITP-02-2018-0095

[3].Al-Fraihat, D., Joy, M., \& Sinclair, J. (2020). Evaluating E-learning systems success: An empirical study. Computers in 
Human Behavior, 102, 67-86. https://doi.org/10.1016/j.chb.2019.08.004

[4].Bhattacherjee, A. (2001). Understanding information systems continuance: An expectation-confirmation model. MIS Quarterly, 351-370. https://doi.org/10.2307/3250921

[5].Bilgihan, A., Barreda, A., Okumus, F., \& Nusair, K. (2016). Consumer perception of knowledge-sharing in travel-related online social networks. Tourism Management, 52, 287-296.

https://doi.org/10.1016/j.tourman.2015.07.0 02

[6].Bressler, S. E., \& Grantham, C. (2000). Communities of commerce: Building internet business communities to accelerate growth, minimize risk, and increase customer loyalty. McGraw-Hill, Inc.

[7].Buranyi, S. (2020). Scathing COVID-19 book from Lancet editor-Rushed but useful. Nature, 582(7813), 478-479. https://doi:10.1038/d41586-020-01839-y

[8].Cabero-Almenara, J., Cejudo, M. del C. L., \& Ortiz, R. V. (2019). THE FORMATIVE SCENARIO OF VIDEOGAMES AND GAMIFICATION: CONTRIBUTIONS FROM PUBLICATIONS IN SPANISH SCIENTIFIC JOURNALS OF EDUCATION AND SOCIAL SCIENCES. In Experiences and perceptions of pedagogical practices with (p. 113).
[9].Cheng, M. (2016). Current sharing economy media discourse in tourism. Annals of Tourism Research, 60, 111-114. https://doi.org/10.1016/j.annals.2016.07.001 [10]. Cheng, Y. (2011). Antecedents and consequences of e- learning acceptance. Information Systems Journal, 21(3), 269299. https://doi.org/10.1111/j.13652575.2010.00356.x

[11]. Cheng, Y.-M. (2015). Towards an understanding of the factors affecting $\mathrm{m}$ learning acceptance: Roles of technological characteristics and compatibility. Asia Pacific Management Review, 20(3), 109119.

https://doi.org/10.1016/j.apmrv.2014.12.011

[12]. Chou, S.-W. (2020). Understanding relational virtual community members' satisfaction from a social learning perspective. Journal of Knowledge Management. https://doi.org/10.1108/JKM12-2019-0683

[13]. Colombo, M., Mosso, C., \& De Piccoli, N. (2001). Sense of community and participation in urban contexts. Journal of Community \& Applied Social Psychology, 11(6), 457-464. https://doi.org/10.1002/casp.645

[14]. Davidson, W. B., \& Cotter, P. R. (1986). Measurement of sense of community within the sphere of City 1. Journal of Applied Social Psychology, 16(7), 608-619. 
https://doi.org/10.1111/j.1559-

1816.1986.tb01162.x

[15]. DeLone, W. H., \& McLean, E. R. (2016). Information systems success measurement. Foundations and Trends ${ }^{\circledR}$ in Information Systems, 2(1), 1-116. https://doi.org/:

http://dx.doi.org/10.1561/2900000005

[16]. Fornell, C., \& Larcker, D. F. (1981). Structural equation models with unobservable variables and measurement error: Algebra and statistics. Journal of Marketing Research, 18(3), 382-388. https://doi.org/10.1177\%2F0022243781018 00313

[17]. Goodhue, D. L., \& Thompson, R. L. (1995). Task-technology fit and individual performance. MIS Quarterly, 213-236. https://doi.org/10.2307/249689

[18]. Hair, J., Black, W., Babin, B., Anderson, R., \& Tatham, R. (2006). SEM: Confirmatory factor analysis. Multivariate Data Analysis. Pearson Prentice Hall, Upper Saddle River, 770-842.

[19]. Hair, Joe F, Sarstedt, M., Ringle, C. M., \& Mena, J. A. (2012). An assessment of the use of partial least squares structural equation modeling in marketing research. Journal of the Academy of Marketing Science, 40(3), 414-433. https://doi.org/10.1007/s11747-011-0261-6 [20]. Hair, Joseph F., Anderson, R. E., Babin, B. J., \& Black, W. C. (2010).
Multivariate data analysis: A global perspective (Vol. 7). Upper Saddle River, NJ: Pearson.

[21]. Hayter, C. S., \& Parker, M. A. (2019). Factors that influence the transition of university postdocs to non-academic scientific careers: An exploratory study. Research Policy, 48(3), 556-570. https://doi.org/10.1016/j.respol.2018.09.009 [22]. Hrastinski, S. (2008). Asynchronous and synchronous e-learning. Educause Quarterly, 31(4), 51-55.

[23]. Huang, E. (2008). Use and gratification in e-consumers. Internet Research.

https://doi.org/10.1108/10662240810897817 [24]. Ifinedo, E., Saarela, M., \& Hämälänen, T. (2019). Analysing the Nigerian Teacher's Readiness for Technology Integration. International Journal of Education and Development Using Information and Communication Technology, 15(3), 34-52.

[25]. Ifinedo, P. (2012). Understanding information systems security policy compliance: An integration of the theory of planned behavior and the protection motivation theory. Computers \& Security, $31(1)$, 83-95. https://doi.org/10.1016/j.cose.2011.10.007 [26]. Isaac, O., Aldholay, A., Abdullah, Z., \& Ramayah, T. (2019). Online learning usage within Yemeni higher education: The 
role of compatibility and task-technology fit as mediating variables in the IS success model. Computers \& Education, 136, 113129.

[27].

Islam, A. N., \& Azad, N. (2015).

Satisfaction and continuance with a learning management system. The International Journal of Information and Learning Technology. https://doi.org/10.1108/IJILT09-2014-0020

[28]. Jacovkis, P. (n.d.). ICT in Latin America: History and social impact. IberoAmerican Journal of Science, Technology and Society-CTS, 6(18).

[29]. Jang, H., Olfman, L., Ko, I., Koh, J., \& Kim, K. (2008). The influence of on-line brand community characteristics on community commitment and brand loyalty. International Journal of Electronic Commerce, 12(3), 57-80. https://doi.org/10.2753/JEC10864415120304

[30]. Jung, Y., \& Lee, J. (2018). Learning engagement and persistence in massive open online courses (MOOCS). Computers \& Education, 122, 9-22.

[31]. Kim, E. Y., \& Kim, Y. (2004). Predicting online purchase intentions for clothing products. European Journal of Marketing, 38(7). https://doi.org/42. https://doi.org/10.1108/03090560410 539302. 642

Copyright $(\odot$ Author
[37]. Lee, D. Y., \& Lehto, M. R. (2013). User acceptance of YouTube for procedural

[32]. Kim, J., Kim, J., \& Wang, Y. (2020). Uncertainty risks and strategic reaction of restaurant firms amid COVID-19: Evidence from China. International Journal of Hospitality Management, 92, 102752. https://doi.org/10.1016/j.ijhm.2020.102752

[33]. Kim, S. H., Yang, K. H., \& Kim, J. K. (2009). Finding critical success factors for virtual community marketing. Service Business, 3(2), 149-171. https://doi.org/10.1007\%2Fs11628-0080059-x

[34]. Kim, T.-Y., Cable, D. M., \& Kim, S.-P. (2005). Socialization tactics, employee proactivity, and person-organization fit. Journal of Applied Psychology, 90(2), 232. https://psycnet.apa.org/doi/10.1037/00219010.90.2.232

[35]. Kolodinsky, J. M., Hogarth, J. M., \& Hilgert, M. A. (2004). The adoption of electronic banking technologies by US consumers. International Journal of Bank Marketing.

https://doi.org/10.1108/02652320410542536

[36]. Kurucay, M., \& Inan, F. A. (2017). Examining the effects of learner-learner interactions on satisfaction and learning in an online undergraduate course. Computers \& Education, 115, 20-37. 10

SSN (Print): 2204-0595 ISSN (Online): 2203-1731 https://doi.org/10.1016/j.compedu.2017.06.0 
learning: An extension of the Technology Acceptance Model. Computers \& Education, 61, 193-208. https://doi.org/10.1016/j.compedu.2012.10.0 01

[38]. Li, X., Song, Y., Wong, G., \& Cui, J. (2020). Bat origin of a new human coronavirus: There and back again. Science China Life Sciences, 63(3), 461-462. https://doi.org/10.1007/s11427-020-1645-7

[39]. Lin, K.-Y., \& Lu, H.-P. (2011). Why people use social networking sites: An empirical study integrating network externalities and motivation theory. Computers in Human Behavior, 27(3), 1152-1161.

https://doi.org/10.1016/j.chb.2010.12.009

[40]. Lin, W.-S., \& Wang, C.-H. (2012).

Antecedences to continued intentions of adopting e-learning system in blended learning instruction: A contingency framework based on models of information system success and task-technology fit. Computers \& Education, 58(1), 88-99. https://doi.org/10.1016/j.compedu.2011.07.0 08

[41]. Liu, Y., \& Beldona, S. (2021). Extracting revisit intentions from social media big data: A rule-based classification model. International Journal of Contemporary Hospitality Management. https://doi.org/10.1108/IJCHM-06-20200592
[42]. Lu, H.-P., \& Yang, Y.-W. (2014). Toward an understanding of the behavioral intention to use a social networking site: An extension of task-technology fit to socialtechnology fit. Computers in Human Behavior, 34, 323-332. https://doi.org/10.1016/j.chb.2013.10.020

[43]. Mayer, R. E. (2019). How multimedia can improve learning and instruction. The Cambridge Handbook of Cognition and Education, 460-479. https://doi.org/10.1017/9781108235631.019

[44]. McGill, T. J., \& Klobas, J. E. (2009). A task-technology fit view of learning management system impact. Computers \& Education, 52(2), 496-508. https://doi.org/10.1016/j.compedu.2008.10.0 02

[45]. McMillan, D. W. (1996). Sense of community. Journal of Community Psychology, 24(4), 315-325. https://doi.org/10.1002/(SICI)15206629(199610)24:4\%3C315::AID-

JCOP2\%3E3.0.CO;2-T

[46]. McMillan, D. W., \& Chavis, D. M. (1986). Sense of community: A definition and theory. Journal of Community Psychology, 14(1), 6-23. https://doi.org/10.1002/15206629(198601)14:1\%3C6::AIDJCOP2290140103\%3E3.0.CO;2-I

[47]. Mesmer-Magnus, J. R., DeChurch, L. A., Jimenez-Rodriguez, M., Wildman, J., 
\& Shuffler, M. (2011). A meta-analytic investigation of virtuality and information sharing in teams. Organizational Behavior and Human Decision Processes, 115(2), 214-225.

https://doi.org/10.1016/j.obhdp.2011.03.002

[48]. Morens, D. M., Taubenberger, J. K., \& Fauci, A. S. (2009). The persistent legacy of the 1918 influenza virus. New England Journal of Medicine, 361(3), 225-229. https://doi.org/10.1056/NEJMp0904819

[49]. Murillo-Zamorano, L. R., Sánchez, J. Á. L., \& Godoy-Caballero, A. L. (2019). How the flipped classroom affects knowledge, skills, and engagement in higher education: Effects on students' satisfaction. Computers \& Education, 141, 103608. https://doi.org/10.1016/j.compedu.2019.103 608

[50]. Negahban, A., \& Chung, C.-H. (2014). Discovering determinants of users perception of mobile device functionality fit. Computers in Human Behavior, 35, 75-84. https://doi.org/10.1016/j.chb.2014.02.020

[51]. Ozturk, A. B., Bilgihan, A., Nusair, K., \& Okumus, F. (2016). What keeps the mobile hotel booking users loyal? Investigating the roles of self-efficacy, compatibility, perceived ease of use, and perceived convenience. International Journal of Information Management, 36(6), 1350-1359. https://doi.org/10.1016/j.ijinfomgt.2016.04.0 05

[52]. Premkumar, G. (2003). A metaanalysis of research on information technology implementation in small business. Journal of Organizational Computing and Electronic Commerce, 13(2), 91-121. https://doi.org/10.1207/S15327744JOCE130 2_2

[53]. Rogers, E. M. (1995). Diffusion of Innovations: Modifications of a model for telecommunications. In Die diffusion von innovationen in der telekommunikation (pp. 25-38). Springer.

[54]. Rosenbaum, M. S., Ostrom, A. L., \& Kuntze, R. (2005). Loyalty programs and a sense of community. Journal of Services Marketing, $\quad$ 19(4), 222-233. https://doi.org/10.1108/08876040510605253 [55]. Ruiz-Equihua, D., Romero, J., \& Casaló, L. V. (2019). Better the devil you know? The moderating role of brand familiarity and indulgence vs. Restraint cultural dimension on eWOM influence in the hospitality industry. Journal of Hospitality Marketing \& Management, 29(3), 310-328. https://doi.org/10.1080/19368623.2019.1630 698

[56]. Schwarzenberg, P., Navon, J., Nussbaum, M., Pérez-Sanagustín, M., \& Caballero, D. (2018). Learning experience 644

SSN (Print): 2204-0595 ISSN (Online): 2203-1731 
assessment of flipped courses. Journal of

Computing in Higher Education, 30(2), 237-258. https://doi.org/10.1007/s 12528017-9159-8

[57]. Sharun, K., Sircar, S., Malik, Y., Singh, R., \& Dhama, K. (2020). How close is SARS- CoV- 2 to canine and feline coronaviruses? The Journal of Small Animal $\begin{array}{lll}\text { Practice, } & 61(8), & \end{array}$ https://doi.org/10.1111/jsap.13207

[58]. Sun, P.-C., Tsai, R. J., Finger, G., Chen, Y.-Y., \& Yeh, D. (2008). What drives a successful e-Learning? An empirical investigation of the critical factors influencing learner satisfaction. Computers \& Education, 50(4), 1183-1202. https://doi.org/10.1016/j.compedu.2006.11.0 07

[59]. Tabachnick, B. G., Fidell, L. S., \& Ullman, J. B. (2007). Using multivariate statistics (Vol. 5). Pearson Boston, MA.

[60]. Tavassoli, S., \& Karlsson, C. (2016). Innovation strategies and firm performance: Simple or complex strategies? Economics of Innovation and New Technology, 25(7), 631-650.

[61]. Tenório, K., Dermeval, D., Monteiro, M., Peixoto, A., \& Pedro, A. (2020). Raising teachers empowerment in gamification design of adaptive learning systems: A qualitative research. 524-536.

[62]. Venkatesh, V., \& Bala, H. (2008). Technology acceptance model 3 and a research agenda on interventions. Decision Sciences, 39(2), 273-315. https://doi.org/10.1111/j.15405915.2008.00192.x

[63]. Vijay, T. S., Prashar, S., \& Sahay, V. (2019). The influence of online shopping values and web atmospheric cues on eloyalty: Mediating role of e-satisfaction. Journal of Theoretical and Applied Electronic Commerce Research, 14(1), 115. http://dx.doi.org/10.4067/S071818762019000100102

[64]. Wang, M., Cho, S., \& Denton, T. (2017). The impact of personalization and compatibility with past experience on ebanking usage. International Journal of Bank Marketing. https://doi.org/10.1108/IJBM-04-2015-0046 [65]. Wang, W., Chen, R. R., Ou, C. X., \& Ren, S. J. (2019). Media or message, which is the king in social commerce?: An empirical study of participants' intention to repost marketing messages on social media. Computers in Human Behavior, 93, 176191.

https://doi.org/10.1016/j.chb.2018.12.007

[66]. Wang, W.-T., Ou, W.-M., \& Chen, W.-Y. (2019). The impact of inertia and user satisfaction on the continuance intentions to use mobile communication applications: A mobile service quality perspective. International Journal of Information Management, $\quad 44, \quad$ 178-193. 
https://doi.org/10.1016/j.ijinfomgt.2018.10.0 11

[67]. Xie, Y., Chen, K., \& Guo, X. (2020). Online anthropomorphism and consumers' privacy concern: Moderating roles of need for interaction and social exclusion. Journal of Retailing and Consumer Services, 55, 102119.

https://doi.org/10.1016/j.jretconser.2020.102 119
[68]. Xinli, H. (2015). Effectiveness of information technology in reducing corruption in China. The Electronic Library. https://doi.org/10.1108/EL-11-2012-0148

[69]. Zhang, R., Li, G., \& Sun, Z. (2014). Relationship between consumer innovativeness and internet banking acceptance. 308-314. https://doi.org/10.1109/ICMSE.2014.693024 5 